\title{
EFFECTS OF RAINFALL INTENSITY AND SLOPE ANGLE ON SPLASH EROSION IN MAKURDI, BENUE STATE
}

\author{
S. A. IORKUA AND C. Y. OCHE
}

(Received 06 July 2012; Revision Accepted 05 September 2012)

\begin{abstract}
Soil erosion is a critical global environmental problem, especially in the developing countries including Nigeria. In the humid and sub-humid tropics, splash erosion resulting from intense rainfall and slope degree pose severe land degradation problems. The objective of this study is to assess the effects of some rainfall parameters and slope on directional components of splash erosion in the Makurdi area of Benue State. Data were collected on rainfall amount and duration in an experimental station in Benue State University, Makurdi for a period of one rainy season in 2007. Sediment collectors attached to soil trays placed at angles 5, 15, 25 and 35 degrees were used to collect the amount of splash at the end of every rain day. The soils were oven dried and measured. The amount of soil splashed was statistically analyzed after weighing to verify the slope effects on splash. The results showed that slope has a significant effect on the downslope and upslope components of the splash. Downslope component increased with slope while the upslope component decreased, reflecting variations of raindrop impacting forces and ponding depth with slope. Total splash increased with slope angle to a peak at $15^{\circ}$ and then decreased with increasing angle. Factors of slope angle, rainfall amount, and intensity, and total kinetic energy were regressed against directional components of splash. The result showed that $70 \%$ of variations in the downslope splash is explained by these factors. Further research is recommended on slope orientations at different wind directions and rate of rain capture on erodibility.
\end{abstract}

KEYWORDS: Splash, erodibility, slope, erosivity, Modeling.

\subsection{INTRODUCTION AND STATEMENT OF THE PROBLEM}

Soil erosion is recognized as a critical global environmental problem that affects the livelihood of millions of people. Problems related to soil erosion; including both on-site productivity decline and off-site water resource impacts among others are obvious and severe in many parts of the world, particularly in Africa (Lal, 1993, 1996a; El-Swaify, 1993 and Collins et al., 2001). Soil loss continues to threaten agricultural production especially in developing countries despite several decades of research studies carried out by soil scientists/conservationists, agricultural engineers, agroclimatologists, geomorphologists, among others (Jeje, L.K., 1988; Schwab, G.O.; Fangmeier, D.D.J.; Ellison W.J.J. and Frevert, R.K, 1993; and Van Dijk A.I.J.M., 2002).

In Nigeria, virtually every part of the country is affected by one type of erosion or the other, and perhaps all types of land use surfaces are affected by soil erosion, even though the type, extent and severity may differ. Wind erosion is active in the semi arid (Sudan and Sahel savanna) north, while sheet and gully erosion are more severe in the forested and wetter south of the country. Most studies on erosion in the humid tropics that touch on the role of vegetation and other factors focus on sheet and gully erosions with little or no attention given to splash process. More importantly too is the effects of agricultural land uses and climate changes on erodibility in a predominantly agrarian place like Benue State, which because of its crop production, has her motto 'The Food Basket of the Nation'.

Splash is very fundamental to soil erosion process such that certain kinds of erosion have been classified as being splash limited or transport limited (Morgan, 1979). Splash erosion is an important slope process because it increases the sediment load of runoff, destroys soil aggregate or structure, creates surface seal or crust which inhibits infiltration, creates splash pedestals or soil pillars and earth/rock pillars, and more importantly, aids in the assessment of erodibility of soils, erosivity of raindrops and the erosion risk of vegetated surfaces (Jeje, 1988; Poesen and Torri, 1988; Eze, 1996).

Understanding of the processes causing detachment and transport by falling rains has improved considerably over the last two decades, mainly through laboratory experiments (Kinnel, 1990; Proflittt and Ross, 1991; Salles \& Poeson, 2000; Heiling et al., 2001). But the results of these experiments are not readily translatable to field situations because natural rainfall and field soils present added complexities that are not easily controlled. 
The objective of this study is to assess the effects of some rainfall parameters and slope on splash erosion in the Makurdi area of Benue State.

\subsection{Conceptual Framework}

The nature and magnitude of erosion are functions of a number of variables, and the concepts of erosivity and erodibility are fundamental in the assessment of soil erosion. This work anchors on these two concepts as the building blocks in the theoretical framework, grouped under the headings of energy, resistance and/or protection (Morgan, 1991).

Erosivity refers to the energy possessed by raindrops that causes erosion (Brand and Thonnes 1978). It involves energy expenditure for breaking down soil cohesiveness, mobilizing soil particles and entraining them in overland flow (Jege, 1987). This energy is very important in splash studies in the humid tropics where the rains are torrential in nature. Erosivity defines the resistance of the soil to both detachment and transport. To compute erosivity requires analyses of the drop size distributions of rain. Drop - size characteristics vary with the intensity of the rain, generally increasing with rainfall intensity. Morgan (1979) reports that this holds only for rainfall intensities up to $100 \mathrm{~mm} \mathrm{~h}^{-1}$ at greater intensities, median drop size decreases with increasing intensity, presumably because greater turbulence makes larger drop sizes unstable.

Another important factor is rainfall kinetic energy (total energy available for detachment and transportation). Results of various studies on erosivity, for example as reported by Van Dijk, (2002) suggest that soil splash rate is a combined function of rainfall intensity and kinetic energy. They, however, recommended a comprehensive assessment of the importance of these various factors influencing erosivity and called for more research involving measurement of drop size and fall velocity distributions on the one hand and soil detachment on the other in natural environmental conditions (including rainfall).

Erodibility on the other hand refers to the susceptibility of the soil to erosion. It is a function of soil aggregate stability, which is affected by different soil properties (Idowu, 2003; Hammad et al., 2005 and Valmis et al., 2005). Erodibility depends mainly on the physico chemical properties of the soil (Lal, 1988), which determines the ease with which the soil is detached, entrained and transported by rain, and the shearing index of surface material. Leopold et al., (1964) consider erodibility as a direct function of the intensity of rain, the infiltration capacity of the surfaces, the chemical and physical properties that control the disintegration of rocks and determine the cohesiveness of the soil, and the vegetation and slope which directly affect both the stability and infiltrating capacity of the soil. According to Aneke (1991), erodibility is dependent on colloidal content, density and mechanical structure of soil.

The measurement of splash generally has continued to present problems to researchers over the years. Isolating the sub-processes involved in splash, particularly in the field (detachment, transport, upslope and downslope detached sediments, splash distance etc), is even more problematic (Van Dijk et al., 2003 and Legout et al., 2005). The difficulties of measuring splash erosion processes have, however aided the development of various techniques aimed at obviating the measurement problems.

The Morgan's cup is so far the most used method of measuring splash in the field, but cannot efficiently sample absolute rate of downslope and upslope splashes because it has the problem of accumulating water in the inner cylinder and catching tray during heavy rains and lack detachable parts thus making it difficult to quantify temporal variations in inter-rill splash and wash transport. Van Dijk et al. (2003) recently used a combined splash and runoff collecting system, modified slightly from the design by Wan et al., (1996).

\subsection{Materials and Methods \\ 2.1 Study Area}

The study is carried out in the Geography Department Agro-Meteorological Station, located at the western part of the Benue State University, Makurdi (lat. $7^{\circ}$ $45^{\prime} \mathrm{N}$ and long. $\left.8^{\circ} 35^{\prime} \mathrm{E}\right)$. The University is sited on the flood plain of river Benue, with an elevation of about $91 \mathrm{~m}$ asl. The slopes are generally gentle at $6^{\circ}-10^{\circ}$ on average (see fig 1). 


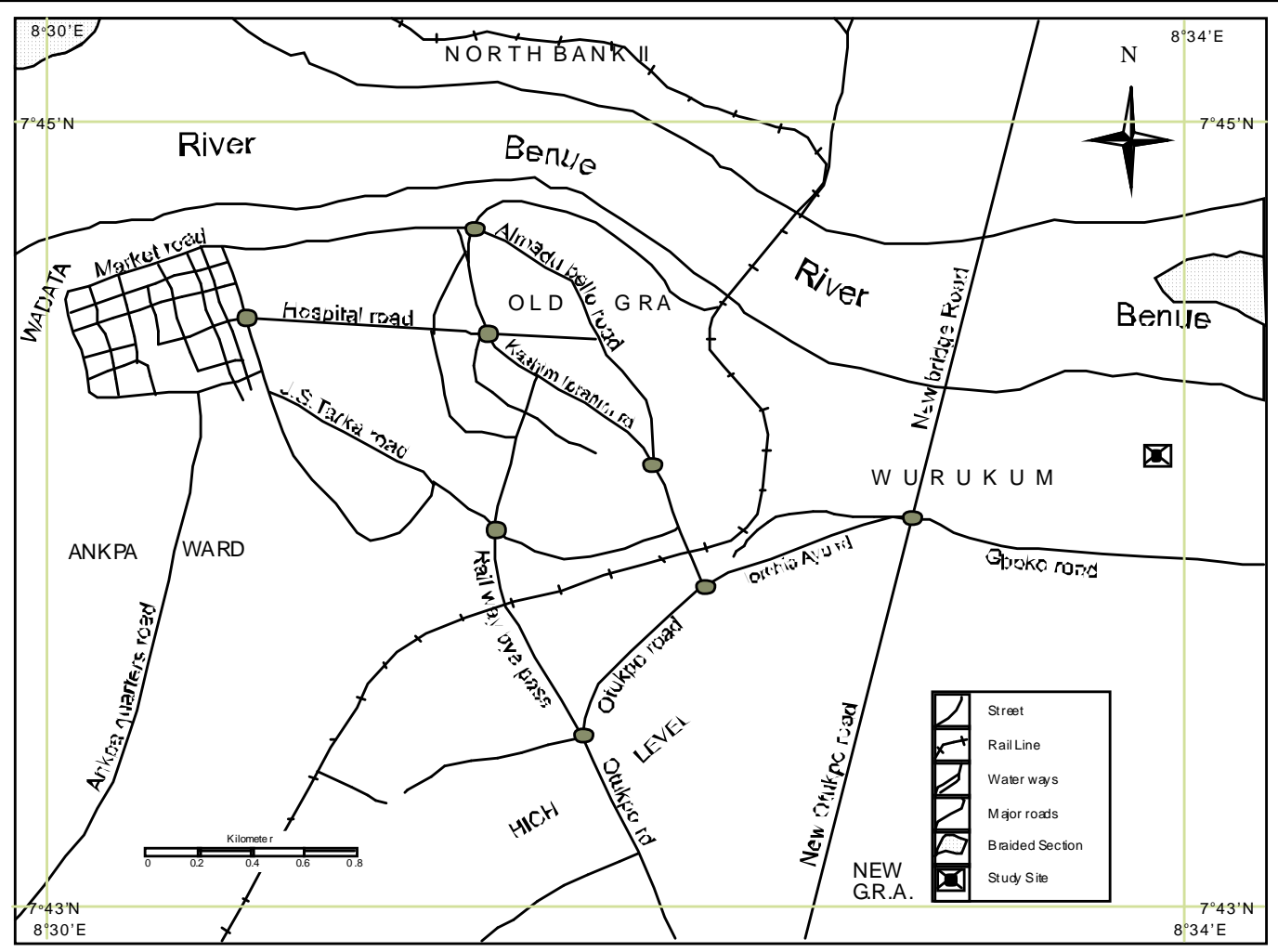

Fig. 1: Makurdi town showing the Study Area Source: Benue State Ministry of Lands and Survey

The major geological formation of the study area is the cretaceous sediment, made up of the false-bedded sandstones, and consisting of poorly sorted thick unconsolidated sandstones, which are white pale gray and sometimes stained red yellow, by iron oxides. The sandstones, mostly alluvial deposits, attain a thickness of up to $900 \mathrm{~m}$. The USDA and FAO classify the soils of the present study area as Typic Haplustuit and Orthic Acrisol respectively (FDALR 1985). The soils are deep, well drained with dark reddish brown sandy loam to sandy clay loam surface over dark red gravelly clay loam. They are acid with low to moderate organic matter content and total nitrogen contents.

The area is generally hot and humid. Temperatures are constantly high throughout the year, averaging $27^{\circ}$ to $31^{\circ} \mathrm{C}$ though it may occasionally escalate to $37^{\circ} \mathrm{C}$ in some days in March and April. The rainfall is moderate, with annual rainfall totals of between $900 \mathrm{~mm}$ and $1500 \mathrm{~mm}$. Wet season lasts for seven months, from April to October. The start or onset of the rains is also unreliable. The rainfalls are mostly convectional and occur at short duration, especially at the beginning and end of the rainy season. This kind of torrential rainfall constitutes a potential agent for soil material detachment and transportation, particularly where it is highly exposed (lorkua 1999).

The Makurdi area, like many other parts of the State, has fairly dense population. Majority of the rural population engage in agricultural production as means of livelihood or for supplementing their income especially by urban dwellers. Hence, intensive land use for crop production and other human activities tend to exacerbate pressure on the land and ultimately expose the land to erosion.

\section{$2.2 \quad$ Methods}

The equipment used in this research consists of a soil tray made from galvanized metal, with dimensions of $0.60 \mathrm{~m} \times 0.30 \mathrm{~m} \times 0.10 \mathrm{~m}$. At the down slope end of the tray, small holes were made to allow for drainage. Four separate detachable splash collectors were placed by the sides of the soil trays by half inch flat rods attached to the bottom of the soil tray. The soil tray was placed on a wooden table measuring $70 \mathrm{~cm}(\mathrm{~L})$ by $40 \mathrm{~cm}(\mathrm{w})$ and $20 \mathrm{~cm}$ $(\mathrm{H})$. The upslope, lateral and downslope splash collectors were attached to the soil tray in a vertical position. The lateral splash collectors have dimensions of $60 \mathrm{~cm}(\mathrm{~L})$ by $30 \mathrm{~cm}(\mathrm{H})$ by $10 \mathrm{~cm}(\mathrm{~W})$ and $10 \mathrm{~cm}$ (D) (plate 1). The upslope and downslope splash collectors have dimensions of $30 \mathrm{~mm}(\mathrm{~L})$ and $30 \mathrm{~cm}(\mathrm{~h})$ and $10 \mathrm{~cm} \mathrm{(w)} \mathrm{and}$ $10 \mathrm{~cm}$ (d). Small perforations were made $1 \mathrm{~cm}$ above the bottom of the splash collectors to allow drainage of excess rain water, while at the same time maintaining a water layer preventing water and sediment from splashing back onto the soil or moving in suspension. Further information on this equipment can be gotten from Wan, et al. (1996) and Van Dijk et al. (2003). 


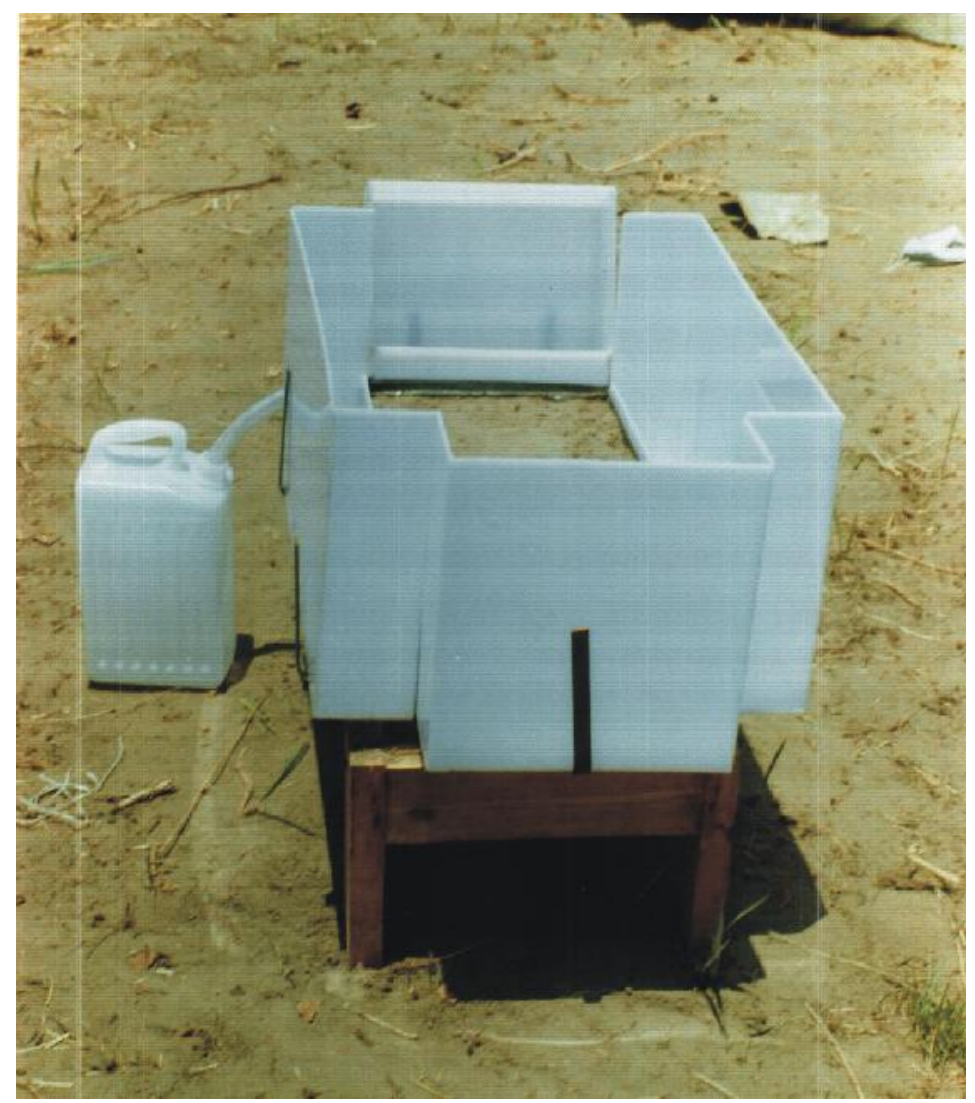

Plate 1: Complete Set of Soil Tray with Splash Collectors Attached

Four (4) separate soil trays, each with four splash collectors (of 2 laterals and 1 each of downslope and upslope) were used in this study to evaluate the effects of slope on directional components of splash. The experiment was set during the dry season, and the soil was neither sieved nor wet before use. The initial moisture content, and aggregation and the other soil properties were determined before the commencement of the experiments. Some soil material were added in June and September to regain the original level. This is consistent with the weeding and/or hoeing of agricultural croplands in this area at this time of year.

Throughout the period of the data collection, the equipments were placed at the same spot and facing the same direction. Slopes studied were $5^{\circ}, 15^{\circ}, 25^{\circ}$, and $35^{\circ}$. Wan et al., (1996) and Van Dijk et al., (2003) used $0^{\circ}, 5^{\circ}$, $15^{\circ}$, and $40^{\circ}$; and $4^{\circ}, 9^{\circ}, 18^{\circ}, 27^{\circ}$, and $36^{\circ}$ respectively in their studies. One tray was placed at each of these slopes. Data collection spanned a period of 7 months, commencing from April 7 and terminating on October 27, 2007.

Descriptive statistics such as mean, standard deviation, and percentages were used to explain the patterns of variation of the elements measured. The inferential statistics such as multiple correlation and regression, and analysis of variance were used to further verify the nature and strength of the inter-dependence / relationships between variables. Three major relationships were explored in the study. These include the regression at the downslope of the independent variables of slope angle, total intensity, total kinetic energy and rainfall amount against splash represented by the equation $\mathrm{Yd}$ $=29.8+1.5 \mathrm{RFM}+0.6 \mathrm{TNT}+4.5 \mathrm{TKE}+1.9 \mathrm{SA} ;$ Where: $\mathrm{Yd}=$ downslope; RFM= rainfall amount; TNT= total intensity; $\mathrm{TKE}=$ total kinetic energy. At the upslope, a corresponding relationship is of the form $\mathrm{Yu}=15.6+1.2 \mathrm{RFM}+0.6 \mathrm{TNT}+$ 0.15TKE + 0.5SA; Where: $\mathrm{Yu}=$ upslope splash, RFM= rainfall amount, $\mathrm{TNT}=$ total intensity, $\mathrm{TKE}=$ total kinetic energy, $\mathrm{SA}=$ slope angle. Similarly, the equation for total splash is of the form $\mathrm{Yt}=-31.7+8.1 \mathrm{RFM}+2.1 \mathrm{TIT}+-$ $0.49 \mathrm{TKE}+1.2 \mathrm{SA}$; Where $\mathrm{Yt}=$ total splash; $\mathrm{RFM}=$ rainfall amount; TNT = total intensity; TKE = total kinetic energy; $S A=$ slope angle. The models for these equations are in appendix $1 \mathrm{~A}-\mathrm{C}$.

\subsection{RESULTS AND DISCUSSION}

The general sequence of splash rates as observed for the $5^{0}$ slope is that upslope splash is generally greater downslope. This is graphically depithed in figs. 2 and 3.

However, a study of the monthly means at this angle $\left(5^{0}\right)$, showed that more splash was recorded at the upslope in April, May, June, September and October. Visual observation by the researcher during some storms showed that there was ponding of sheet flow present in the downslope area of the $\left(5^{0}\right)$ slope. The water layer most likely had a cushioning effect and shielded soil from splash. This effect has been documented by Moss and Green (1983), Proffitt and Ross (1991) and Wan et al. 
(1996). Water flow at the upslope areas was faster and so the effect of ponding was not experienced. The splash at this angle $\left(5^{0}\right)$ may also have been markedly affected by the combined effect of wind and the direction the droplets strike the soil.
The effect of wind and the direction of strike by droplets were observed during some of the storms. The effect of the droplets on direction of splashed soil has been documented by Schwab et al. (1993).

Table 1: Mean monthly directional splash in grams

\begin{tabular}{|c|c|c|c|c|c|c|}
\hline \multirow{2}{*}{ Months } & \multicolumn{6}{|c|}{ Control (without mulch) } \\
\hline & N/S & SA & DS & US & LS & тот \\
\hline April & 5 & $5^{\circ}$ & 34.64 & 59.78 & 128.86 & 238.68 \\
\hline April & 5 & $15^{\circ}$ & 52.88 & 47.64 & 241.90 & 342.42 \\
\hline April & 5 & $25^{\circ}$ & 90.72 & 36.36 & 186.20 & 313.28 \\
\hline April & 5 & $35^{\circ}$ & 78.62 & 42.42 & 203.58 & 324.62 \\
\hline May & 7 & $\begin{array}{l}5^{\circ} \\
15^{\circ}\end{array}$ & 25.13 & 42.40 & 101.01 & 168.54 \\
\hline May & 7 & & 41.74 & 37.08 & 109.41 & 188.23 \\
\hline May & 7 & $25^{\circ}$ & 43.84 & 29.86 & 112.41 & 187.24 \\
\hline May & 7 & $\begin{array}{l}35^{\circ} \\
5^{\circ}\end{array}$ & 64.03 & 12.99 & 103.18 & 180.19 \\
\hline June & 8 & 5 & 40.06 & 50.84 & 164.93 & 255.85 \\
\hline June & 8 & $15^{\circ}$ & 56.50 & 53.69 & 175.14 & 285.36 \\
\hline June & 8 & & 89.01 & 32.03 & 182.51 & 292.61 \\
\hline June & 8 & $\begin{array}{l}35^{\circ} \\
5^{\circ}\end{array}$ & 114.74 & 19.13 & 150.53 & 281.75 \\
\hline July & 8 & $5^{\circ}$ & 24.86 & 14.47 & 65.31 & 104.66 \\
\hline July & 8 & $\begin{array}{l}15 \\
25^{\circ}\end{array}$ & 28.67 & 9.10 & 56.90 & 95.07 \\
\hline July & 8 & $\begin{array}{l}25^{\circ} \\
25^{\circ}\end{array}$ & 39.36 & 3.30 & 53.13 & 95.64 \\
\hline July & 8 & $\begin{array}{l}35^{\circ} \\
5^{\circ}\end{array}$ & 42.56 & 2.35 & 42.54 & 85.71 \\
\hline August & 10 & $\begin{array}{l}5 \\
15^{\circ}\end{array}$ & 30.68 & 20.72 & 75.77 & 127.17 \\
\hline August & 10 & $\begin{array}{l}15^{\circ} \\
25^{\circ}\end{array}$ & 51.37 & 18.44 & 78.00 & 145.50 \\
\hline $\begin{array}{l}\text { August } \\
\text { August }\end{array}$ & 10 & $\begin{array}{l}25 \\
35^{\circ}\end{array}$ & 56.28 & 9.00 & 73.07 & 136.55 \\
\hline $\begin{array}{l}\text { August } \\
\text { Sentem }\end{array}$ & 10 & $\begin{array}{l}35^{\circ} \\
5^{\circ}\end{array}$ & 58.60 & 5.58 & 58.63 & 120.58 \\
\hline $\begin{array}{l}\text { ber } \\
\text { Septem }\end{array}$ & 11 & $15^{\circ}$ & 24.66 & 25.46 & 77.98 & 128.19 \\
\hline $\begin{array}{l}\text { ber } \\
\text { Septem }\end{array}$ & 11 & $25^{\circ}$ & 37.32 & 23.52 & 95.27 & 155.90 \\
\hline $\begin{array}{l}\text { ber } \\
\text { Septem }\end{array}$ & 11 & $35^{\circ}$ & 47.76 & 15.30 & 77.63 & 140.69 \\
\hline $\begin{array}{l}\text { ber } \\
\text { October }\end{array}$ & 11 & $5^{\circ}$ & 55.80 & 8.79 & 62.46 & 123.30 \\
\hline Octoher & 10 & 5 & 3.26 & 7.03 & 26.12 & 36.43 \\
\hline October & 10 & $\begin{array}{l}15^{\circ} \\
25^{\circ}\end{array}$ & 22.27 & 14.29 & 82.65 & 119.21 \\
\hline Octurer & 10 & 25 & 29.12 & 9.13 & 60.00 & 98.25 \\
\hline October & 10 & 3 & 46.08 & 4.12 & 75.56 & 126.26 \\
\hline
\end{tabular}

Source: Raw data from the field, 2007:

$\mathrm{N} / \mathrm{S}=$ No. of storms; $\mathrm{SA}=$ slope Angle; $\mathrm{DS}=$ downslope; $\mathrm{US}=$ upslope; $\mathrm{LS}=$ lateral side and $\mathrm{TOT}=$ total 


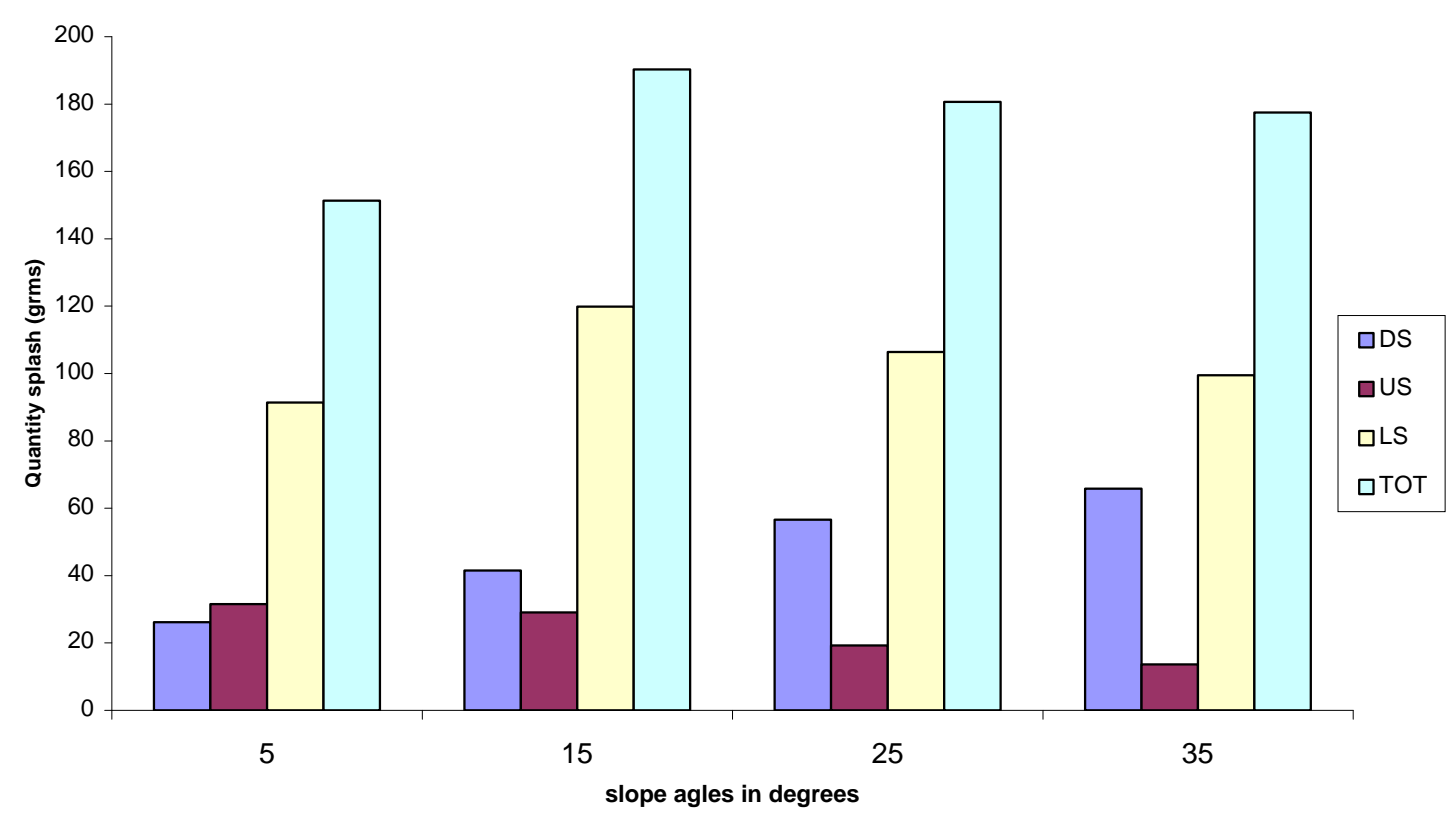

Fig 2. Mean annual directional components of splash

The implication of this result is that, at lower slopes $\left(5^{0}\right)$, the effects of slope angle is not a determining factor in the direction of movement of splashed soil. At steeper slopes, there is continuous increase of splash downslope with increasing slope angle. In terms of comparison between downslope and upslope, no month recorded more splashes at the upslope than downslope from $15^{\circ}$ and above. This was also the conclusion of Van Dijk et al. (2003) who noted in their study that downslope splash increased with slope, whereas upslope splash decreased. According to these authors, lateral splash did not show any obvious trend along the same lines. As in the present study, the authors noted decrease in the upslope splash with slope increase. Figure 4 shows mean annual splash pattern. The increase in downslope splash rates and decrease in upslope splash rates with increasing slope (figs 2\&3) can be understood from the stand-point of mechanics of splash erosion. Raindrop impact creates a series of normal forces perpendicular to the soil surface and shear forces parallel to the soil surface (Wan et al. 1996). These forces interact and cause sediment movement. At the lower slope, normal forces are stronger and so the distribution of splashed sediments will be determined by factors other than slope. As slope increases, both the normal and shear forces in the upslope direction decreases and the shear forces in the downslope direction increases, resulting in a decreased upslope splash rates and increased downslope splash rates. 


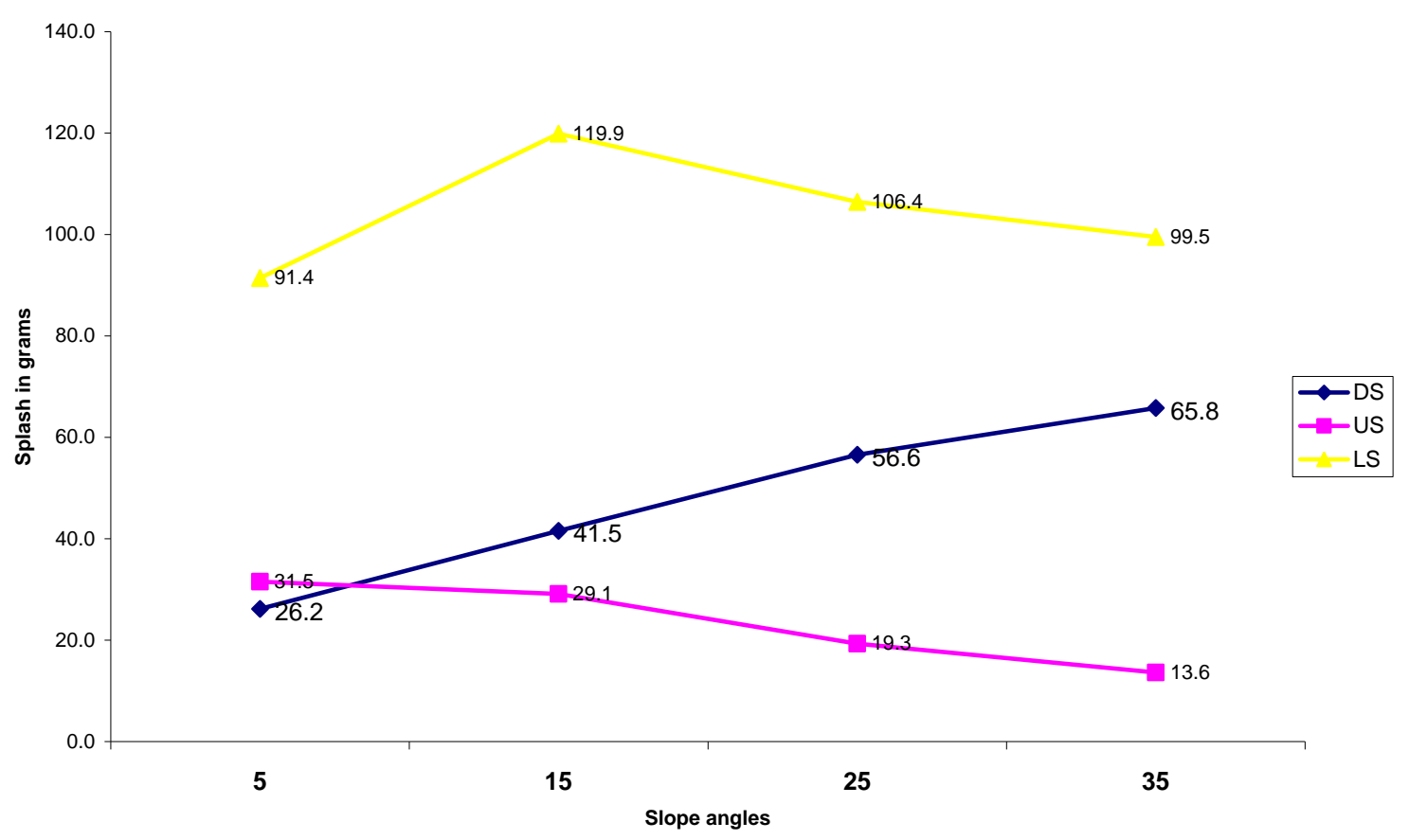

FIG 3 Effect of slope angle on directional splash

Unlike the study by Wan et al. (1996), the data for the present study showed that the total splash output (combining upslope, downslope and lateral sides) from the studied $0.18 \mathrm{~m}^{2}$ plot increased with slope and then decreased after a peak splash rate was reach at $15^{\circ}$ slope. This was also the conclusion of Bryan (1979) and Sutherland et al. (1996).

These results showed that total splash detachability is not just affected by slope angle, but is also influenced by other factors including surface sealing, infiltration, wind, rainfall parameters and soil characteristics. Soil loss generally could be transport limited or detachment limited. The limiting factors include surface sealing, infiltration, slope steepness and rainfall characteristics. At lower slopes, the erosion is usually transport-limited, whereby not all detached sediments are transported. For steeper slopes, the erosional process becomes detachment limited, where all detached sediments are transported (Foster, 1990; Nearing et al., 1990; Wan et al., 1996 and Assouline and Ben- Hur, 2006).

The strength of the influence of the factors of rainfall parameters (amount, intensity, kinetic energy, drop size and its distribution, velocity and momentum) and slope angle are crucial to the quantity of materials detached per unit area (Govers 1991, and Eze 1996). In the present study, only erosivity factors of rainfall amount, $(\mathrm{R} / \mathrm{f}$ amt), total intensity (TNT) and total kinetic energy were used to assess their effects (along with slope angle) on splash. At the downslope, the independent variables of slope angle, total intensity, total kinetic energy and rainfall amount were jointly regressed against splash. The joint contribution of these independent variables to variations in splash at the downslope section was found to be significant. These factors explained $70 \%$ of the variations in downslope splash with slopes studied. However, it was only the contributions of rainfall amount and slope angle that were significant as factors responsible for variations in splash with angles. Total intensity and total kinetic energy did not relate significantly with splash detachment downslope. Total kinetic energy was particularly highly insignificant. The remaining percentage not explained $(30 \%)$ may be due to other factors like the influence of slope angle on ponding and surface crusting/sealing as well as erosivity factors of drop size velocity and momentum.

The variation in splash with slope angle was also investigated using the multiple regression technique at the upslope section, using the same independent variables of slope angle, total intensity, total kinetic energy and rainfall amount. The regression of the independent variables on splash showed that jointly, they explain $80 \%$ of the variations in upslope splash with slope gradient. Twenty percent of the variation is not explained by the above factors. The unexplained factors may include the effects of wind and/or the direction of strike of rain droplets (Schwab et al. 1993), among other factors.

Three of these variables, slope angle, rainfall amount and total intensity were found to be significant at the 0.05 level. While rainfall amount and total kinetic energy were positively significant, slope angle was negatively significant. The implication of the results is that slope angle negatively relates with splash detachment, meaning that as slope angle increases there is decrease 
in splash detachment at the upslope, whereas increase in rainfall and TNT means increase in splash with slope angle.

The relationship between total splash output and the independent variables of slope angle, rainfall amount, total intensity and total kinetic energy was also subjected to the multiple regression statistics. This relationship is highly significant at the 0.05 level. The regression of the independent variables on splash, showed that jointly, they explain $84 \%$ of the variation in total splash with variation in slope. However, only the factor of rainfall amount significantly relates with variation in splash with slopes. The other independent variables of slope angle, TNT and TKE do not relate significantly with total splash at the varied slopes. Morgan, (1978) did not observe any relationship between total splash and slope angle in his study.

\subsection{CONCLUSION}

Soil erosion remains a serious problem especially in agriculturally dominated area such as in Benue State, Nigeria. The rate of soil splash / erosion is a function of a number of factors. This study shows that slope angle and rainfall amount significantly affect splash rates. This observation directly and indirectly impact on the farming practices and crop productivity in the area. Mulching is therefore recommended to farmers as a way of reducing splash erosion.

\section{REFERENCES}

Aneke, D. O., 1991. Erodibility of Luvisol and Luvisol/ Cambisol of Benue State: Journal of Nigerian Agricultural Sciences and Technology I, (1): 5053.

Assouline, S and Ben - Hur, M., 2006. Effects of Rainfall Intensity and Slope Gradient on the Dynanies of Interrill Erosion during Soil Surface Sealing Catena.

Brand, C Jane and John B. Thormes., 1978. Erosional Energies In: Energies of Physical Environments (Ed) Gregory, J.K John Wiley Sons Ltd.

Bryan, R. B., 1979. The Influence of Slope Angle on Soil Entrainment by Sheet Wash and Rain Splash. Earth Surface Processes 43-58.

Collins, A. L., Walling, D. E., Sichingabula, H. M and Leeks, G. J. L., 2001. suspended Sediment Source Fingerprinting in a Small Tropical Catchments and some Management Implications. In Applied Geography 21, (387-412)

El-swaify, S. A., 1993. Sol Erosion and Conservation in the Humid Tropics. Inn D.Pimental, World Soil Erosion and Conservation (pp 233-255). Cambridge University Press
Eze, B. E., 1996. Rainsplash Detachment under Different Land use Surfaces in a Humid Tropics Environments, Unpublished Ph.D. Thesis, University of Ibadan, Ibadan.

FDALR., 1985. The Reconnaissance Soil Survey of Benue State of Nigeria. Soil Report $(1: 250,000)$.

Foster, G. R., 1990. Process based modeling of Soil erosion by Water on agricultural Land. John Wiley, London 429-446.

Govers, G., 1991. Spatail and Temporal Variations in Splash Detachment: a Field Study. Catena Suplement (20): 15-24.

Hammad, A. H. A., Borresen, T and Haugen, L. E., 2005. Effects of Rain Characteristics and Terracing on Runoff and Erosion under the Mediterranean, Soil \& Tillage Research.

Heiling, A., DeBruyn, D., Walter, M. T., Ross, C. W., Parlange, J. Y., Steenhuis, G. C., Harisine, P. B., Hogart, W. L and Walter, L. P., 2001. Testing a Mechanistic Soil Erosion Model with a Sample Experiment. Journal of Hydrology (244): 9-16.

Idowu, O. J., 2003. Relationship between Aggregate Stability and Selected Soil Properties in Humid Tropical Environment. Common, Soil Sc. Plant. Anal. 34, 695-708.

lorkua, S. A., 1999. A Gully in the North Bank Area of Makurdi. Unpublished M. Sc. Thesis of the Department of Geography, University of Ibadan, Ibadan.

Jeje, L. K., 1987. Runoff Soil Erosion Loss from Erosion Plots in Ife Area of South Western Nigeria in Gardinary V. (ed) International Geomorphology Part 11, 459-471.

Jeje, L. K., 1988. Soil Erosion Characteristics Processes and Extent in the Lowland Rainforest Area of South-Western Nigeria. In Sagay, V.O. et al (eds) Ecological Disasters in Nigeria. Soil Erosion, Federal Ministry of Science \&Technology, Lagos 69-83.

Kinnell, P. L. A., 1990. The Mechanics of RaindropInduced Flow Transport. Australian Journal of Soil Research (28): 497-517.

Lal, R., 1988. Soil Erosion Research Methods. Soil and Water Conservation Society, the Netherlands (Wagerningen).

Lal, R., 1993a. Soil Erosion and Conservation in West Africa. In D. Pimentel World Soil Erosion and Conservation (Pp. 7-25). Cambridge University Press. 
Lal, R., 1996a. Deforestation and land -use Effects on Soil Degradation and Rehabilitation in Western Nigeria, in Soil and Tillage Research, 48, 103114.

Legout, C., Leguedois, S., Bissonnais, Y and Malam Issa., O., 2005. Splash Distance and Size Distributions for Various Soils, In, Geoderma, 124, 279-292.

Leopold, L. B., Wolman, M. G and Miller, J. P., 1964. Fluvial Processes in Geomorphology, Freeman Press Co.

Morgan, R. P. C., 1979. Topics in Applied Geography. Soil Erosion. Longman, London.

Morgan, R. P. C., 1991. Soil Erosion and Conservation, Longman. U.K.

Moss, A. J and Green, P., 1983. Movement of solids in air and water by raindrop impact: effect of drop-size and water depth variation. Aust. J. Soil Res. , (21): 257-269.

Nearing, M. A., Lane, J. L., Albert, E. E and Laflen, J. M., 1990. Prediction technology for soil erosion by water status and research needs. Soil. Sc. Soc. Am.J., $54,1702-1711$.

Poesen, J. and Torri, D., 1988. The Effect of cup size on Splash Detachment \& Soil Transport Measurements Part II. Field Measurements, Catena Supplement 12, 113-126.

Proffitt, A. P. B and Ross, C. W., 1991. Soil Erosion Process, I. The Relative Importance of Rainfall Detachment Runoff Environment, Australian Journal of Soil Research. 29, 671-683.
Salles, C and Poeson, J., 2000. Rain Properties controlling Soil Detachment. Hydrological Processes (14): 271-282.

Schwab, G. O., Fangmeier, D. D. J., Ellison, W. J. J and Frevert, R. K., 1993. Soil and Water Conservation Engineering, John Wiley and Sons, Inc. New York.

Sutherland, R. A., Klamy, Zeighlev, A. D., Lee, C. T and El-Swaify, S. A., 1996. Splash \& Wash Dynamics: An Experimental Investigation using an Oxisol. Geoderma (69): 85-103.

Valmis, S. Dimoyiannis, D and Danalatas, N. G., 2005. Assessing Interrill Erosion rate from Soil Aggregate Instability Indus, Rainfall Intensity ad Slope Angle on Cultivated Soils in Central Greece; Soil and Tillage Research. 80, 139-147.

Van Dijk., A. I. J. M., 2002. Water \& Sediment Dynamics in Benchterraced Agricultural Steep lands in West Java, Indonesia, Ph.D. Thesis Vrijie Universiteit, Amsterdam.

Van Dijk, A. I. J. M., Bruijnzeel, L. A and Eisma, L. C. C. H., 2003. A Methodology to Study Rain Splash and Wash Processes under Natural Rainfall. Hydrological processes 17: 153-167.

Wan, Y., El-Swaify, S. A and Sutherland, R. A., 1996. Partitioning Inter rill Splash and Wash Dynamics: A Novel Laboratory Approach. Soil Technology (9): 55-69. 


\section{APPENDIX 1A}

\begin{tabular}{lllll}
\multicolumn{5}{c}{ Model Summary } \\
Model & $\mathrm{R}$ & R Square & $\begin{array}{l}\text { Adjusted } \\
\text { Square }\end{array}$ & RStd. Error of the \\
1 & & & Estimate \\
1 & .837 & .701 & .684 & 31.5118
\end{tabular}

a Predictors: (Constant), Slope angle, TKE, R/F Amt., TIT

\begin{tabular}{|c|c|c|c|c|c|c|}
\hline \multirow[b]{2}{*}{ Model } & \multicolumn{6}{|c|}{ ANOVA } \\
\hline & & $\begin{array}{l}\text { Sum } \\
\text { Squares }\end{array}$ & ofdf & Mean Square & $\mathrm{F}$ & Sig. \\
\hline 1 & Regression & 165457.439 & 4 & 41364.360 & 41.656 & .0 \\
\hline & Residual & 70502.448 & 71 & 992.992 & & \\
\hline & Total & 235959.887 & 75 & & & \\
\hline
\end{tabular}

a Predictors: (Constant), Slope angle, TKE, R/F Amt., TIT

b Dependent Variable: DS-Control

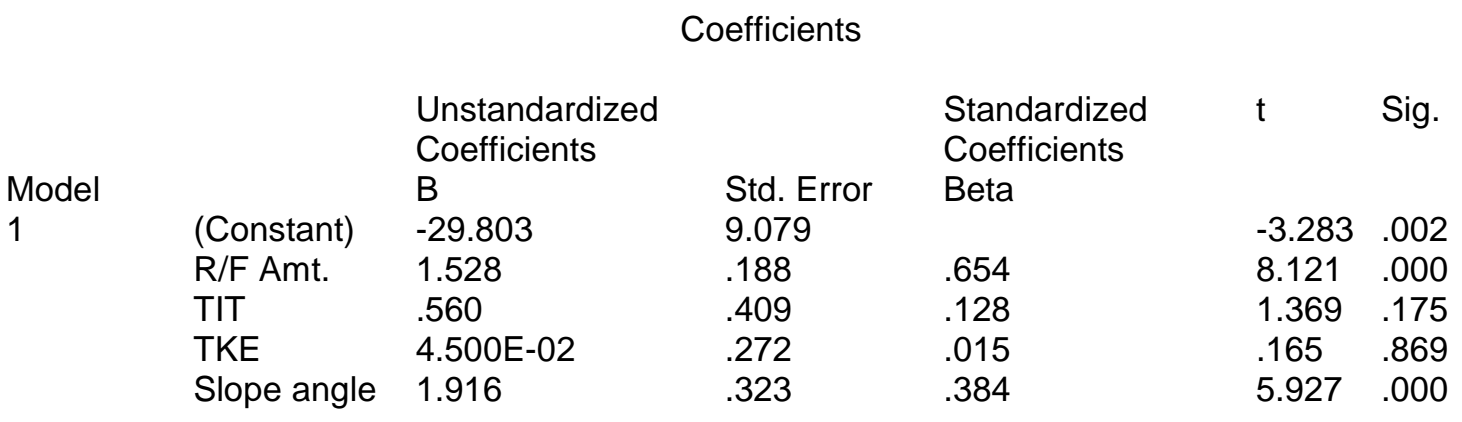

a Dependent Variable: DS-Control 


\section{APPENDIX 1B}

Model Summary

$\begin{array}{lllll}\text { Model } & \mathrm{R} & \mathrm{R} \text { Square } & \begin{array}{l}\text { Adjusted } \\ \text { Square }\end{array} & \mathrm{RStd} \text {. Error of the Estimate } \\ 1 & .894 & .799 & .787 & 17.0574\end{array}$

a Predictors: (Constant), Slope angle, TKE, R/F Amt., TIT

\begin{tabular}{lllllll} 
& \multicolumn{5}{c}{ ANOVA } \\
Model & & Sum of Squares & df & Mean Square & F & Sig. \\
1 & Regression & 81984.555 & 4 & 20496.139 & 70.444 & .000 \\
& Residual & 20657.824 & 71 & 290.955 & & \\
& Total & 102642.379 & 75 & & &
\end{tabular}

a Predictors: (Constant), Slope angle, TKE, R/F Amt., TIT

b Dependent Variable: US-Control

\begin{tabular}{|c|c|c|c|c|c|c|}
\hline & & & icients & & & \\
\hline & & Unstandardized & & Standardized & $\mathrm{t}$ & Sig. \\
\hline Model & & B & $\begin{array}{l}\text { Std. } \\
\text { Error }\end{array}$ & Beta & & \\
\hline 1 & (Constant) & 15.632 & 4.914 & & 3.181 & .002 \\
\hline & $\mathrm{R} / \mathrm{F}$ Amt. & 1.156 & .102 & .751 & 11.356 & .000 \\
\hline & TIT & .589 & .222 & .205 & 2.656 & .010 \\
\hline & TKE & -.148 & .147 & -.073 & -1.001 & .320 \\
\hline & Slope angle & -.959 & .175 & -.292 & -5.482 & 000 \\
\hline
\end{tabular}

a Dependent Variable: US-Control 


\section{APPENDIX 1C}

\begin{tabular}{lllll} 
Model & $\mathrm{R}$ & $\mathrm{R}$ Square & \multicolumn{1}{c}{$\begin{array}{l}\text { Adjusted } \\
\text { Square }\end{array}$} & RStd. Estimate \\
1 & .917 & .841 & .832 & 92.4405
\end{tabular}

a Predictors: (Constant), Slope angle, TKE, R/F Amt., TIT

\begin{tabular}{lllllll}
\multicolumn{7}{c}{ ANOVA } \\
Model & & Sum of Squares & df & Mean Square & F & Sig. \\
1 & Regression & 3215858.278 & 4 & 803964.570 & 94.083 & .000 \\
& Residual & 606712.801 & 71 & 8545.251 & & \\
Total & 3822571.079 & 75 & & &
\end{tabular}

a Predictors: (Constant), Slope angle, TKE, R/F Amt., TIT b Dependent Variable: TOT-Control

\begin{tabular}{|c|c|c|c|c|c|c|}
\hline & & & Coefficient & & & \\
\hline & & $\begin{array}{l}\text { Unstandardized } \\
\text { Coefficients } \\
\text { B }\end{array}$ & Std Error & $\begin{array}{l}\text { Standardized } \\
\text { Coefficients } \\
\text { Beta }\end{array}$ & $\mathrm{t}$ & Sig. \\
\hline 1 & (Constant) & -31.740 & 26.632 & & -1.192 & .237 \\
\hline & $\mathrm{R} / \mathrm{F}$ Amt. & 8.103 & .552 & .862 & 14.682 & .000 \\
\hline & TIT & 2.103 & 1.201 & .120 & 1.751 & .084 \\
\hline & TKE & -.489 & .799 & -.040 & -.612 & .542 \\
\hline & Slope angle & 1.157 & .948 & .058 & 1.220 & .226 \\
\hline
\end{tabular}

a Dependent Variable: TOT-Control 